\title{
Non-secretory multiple myeloma presenting as primary plasma cell leukaemia
}

\author{
A. Sureda, J.R. Pais ${ }^{1}$, J. Pascual ${ }^{2}$, M.A. Pérez Vaquero and J.C. Hernando ${ }^{1}$ \\ Departments of Haematology, ${ }^{1}$ Internal Medicine and ${ }^{2}$ Nephrology, Hospital Ramón y Cajal, Madrid, \\ Spain
}

\begin{abstract}
Summary: A case of non-secretory multiple myeloma presenting as primary plasma cell leukaemia in a 65 year old woman is presented. Bone pain was the initial clinical manifestation. Laboratory analysis showed $20 \%$ of circulating immature plasma cells. Despite the presence of osteolytic lesions, no M-component could be demonstrated in serum protein electrophoresis, and serum and urine immunoelectrophoresis. Bone marrow aspirate demonstrated an $83 \%$ infiltration of plasma cells showing various degrees of immaturity. Immunofluorescence with monoclonal antisera demonstrated intracytoplasmic kappa light chains in a high percentage of plasma cells. Immature plasma cells without cellular capacity to synthesize and excrete complete immunoglobulins could be more aggressive, leading to an initial leukaemic process. Previous work regarding possible pathogenetic mechanisms, clinical and laboratory features, and response to treatment of this extremely rare association are reviewed.
\end{abstract}

\section{Introduction}

Non-secretory multiple myeloma (MM), characterized by the absence of detectable heavy or light chains in the serum and urine, is rare, constituting an estimated $1-4 \%$ of all MM cases. ${ }^{1}$ Plasma cell leukaemia (PCL) is a malignant plasma cell dyscrasia due to proliferation of these cells in the bone marrow, peripheral blood and visceral organs with an incidence of $1.6-2 \%$ that of $M M^{2}$ Only a few well-documented cases of non-secretory MM presenting as primary PCL have been reported..$^{3-7}$

The case history of a patient with concomitant non-secretory MM and primary PCL is presented, and the literature on clinical features and response to chemotherapy of this exceedingly rare association is reviewed.

\section{Case report}

A 65 year old woman was admitted because of increasing bone pain, which started 20 days prior to admission in the left shoulder and ribs. Clinical examination was unremarkable except for tenderness on the anterior archs from fifth and sixth left ribs. Laboratory studies disclosed erythrocyte sedimentation rate $65 \mathrm{~mm}$ per hour, haemoglobin

Correspondence: Anna Sureda, M.D., Rosselló, 340-344 32 Esc. dcha., 08025 Barcelona, Spain.

Accepted: 28 October 1991
$8.3 \mathrm{~g} / \mathrm{dl}$, mean corpuscular volume $93 \mathrm{fl}$ and $\stackrel{\oplus}{\oplus}$ platelet count $140 \times 10^{9} / 1$. White cell count was ? $13.2 \times 10^{9} / 1$ with $20 \%$ immature plasma cells. Ino the peripheral blood smear, rouleaux, marked? anisocytosis and $6 \%$ circulating erythroblasts were observed. Serum creatinine was $124 \mu \mathrm{mol} / 1$, uric acid $524 \mu \mathrm{mol} / \mathrm{l}$, serum calcium $2.62 \mathrm{mmol} / 1$ and serum phosphate $2.13 \mathrm{mmol} / \mathrm{l}$. Total protein was $49.4 \mathrm{~g} / \mathrm{l}$. Immunoelectrophoresis of serum with oligo- and monospecific antisera showed markedly decreased levels of IgG, IgA and IgM: 3, 0.34 and $0.24 \mathrm{~g} / \mathrm{l}$, respectively. Immunoelectrophoresis of the urine concentrated 100 -fold failed to demonstrate light chains. Bone X-ray showed osteolytic punched-out lesions in the skull, left humerus, left clavicle and anterior arch of fifth and sixth left ribs. A compression fracture of the first lumbar vertebra was observed.

Bone marrow aspirate-biopsy disclosed a hypercellular marrow with an infiltration of $83 \%$ by plasma cells of different sizes, with immature features, some of them binucleated. Occasional mitoses could be seen. Examination of the marrow using fluorescein-conjugated antisera specific for each of the immunoglobulin heavy chains and for kappa and lambda light chains showed that the vast majority of plasma cells contained kappa chains in their cytoplasm.

The patient was diagnosed as having nonsecretory $\mathrm{MM}$ presenting as primary $\mathrm{PCL}$ and treatment with combination chemotherapy (M2 protocol: cyclophosphamide $400 \mathrm{mg} / \mathrm{m}^{2}$ i.v. $\times 1$, 
vincristine $1.2 \mathrm{mg} / \mathrm{m}^{2}$ i.v. $\times 1, \quad$ BCNU $20 \mathrm{mg} / \mathrm{m}^{2}$ i.v. $\times 1$, melphalan $10 \mathrm{mg} / \mathrm{m}^{2}$ p.o. $\times 4$ and prednisone $40 \mathrm{mg} / \mathrm{m}^{2}$ p.o. $\times 4$ ) was initiated. The response was excellent with complete clearance of plasma cells from the peripheral blood within the first 4 days of treatment. She continues to receive cyclic chemotherapy and is in complete remission with a follow-up of 4 months.

\section{Discussion}

Non-secretory MM was described more than 20 years $\mathrm{ago}^{8}$ and is characterized by the absence of an M-component in serum and urine. It represents less than $1 \%$ of all the patients diagnosed of having MM. ${ }^{1,9,10}$ PCL probably represents one of the rarest forms of acute leukaemia occurring in up to $5 \%$ of the patients with plasmatic dyscrasias.,11,12 The diagnosis is usually established by the demonstration of circulating plasma cells in numbers either $>20 \%$ of the total white-cell count or $>0.2 \times$ $10^{9} / 1 .{ }^{11,12} \mathrm{PCL}$ can occur as a terminal event in the evolution of MM (secondary PCL) or as a presenting feature, in a patient with no previous history of plasma cell dyscrasia (primary PCL).

The coexistence of non-secretory $\mathrm{MM}$ and primary PCL in the same patient is of clinical interest. To the best of our knowledge, this association has only been described in six other individuals. Bone pain was present as the initial clinical symptom in six out of seven patients, four of whom were female. Osteolytic lesions, reported to be more frequent in secondary than in primary $P C L,, 13,14$ were observed in $70 \%$ of the patients. Organomegaly was not as frequent as in $\mathrm{PCL}^{11,14}$ only $28 \%$ of the patients had hepatomegaly at diagnosis and none had splenomegaly or peripheral lymphadenopathy. Mild to moderate anaemia was present in four out of six patients. Serum calcium and creatinine were within normal limits in all but one patient, renal function impairment appears to be less frequent in non-secretory $M M$ than in the secretory type. ${ }^{6,15}$ Hypogammaglobulinemia occurred in most of the seven patients reviewed. This fact is in accordance with some authors, ${ }^{6,16,17}$ although others have found normal polyclonal immunoglobulin levels. ${ }^{10}$ Chemotherapy regimens varied from one patient to another.

Response to treatment was generally poor with three of the seven patients reaching a complete remission and survival short: four patients died within the first $\mathbf{4 5}$ days from diagnosis. Survival was not related to treatment received. There are conflicting opinions on the evolution and clinical response of $\mathrm{MM}$ with no $\mathbf{M}$-component: although a bad prognosis was first reported ${ }^{16,18}$ in recent reports there was no significant difference between the non-secretory and the secretory type of $\mathbf{M M}^{17,19}$ and even a better prognosis could be supposed on the basis of a spared renal function. ${ }^{9,17,20}$ On the other hand, primary PCL is an aggressive disease considered to have developed from the most immature plasma cells: median survival of these patients is generally short (range 2-6.8 months) with poor response to the chemotherapy administered. ${ }^{2,5,7,11,12,21}$

Non-secretory MM can be difficult to diagnose and distinguish from carcinomatous infiltration of the bone marrow in elderly patients with skeletal disseminated lytic lesions ${ }^{22}$ sometimes leading to erroneous initial diagnosis. ${ }^{23}$ With the improvement of diagnostic tools, it has been possible to demonstrate two different situations in MM with no M-component: (1) patients with positive immunofluorescence in plasma cells (secretory non-excretory $\mathrm{MM})^{5,6,9,16,18,20,24}$ and (2) patients with negative immunofluorescence (true nonsecretory MM). ${ }^{9,18,23,25}$ The patient we present has to be included in the first group with the demonstration of intracytoplasmic kappa chains with monospecific antisera immunofluorescence. The diagnosis of primary PCL may also be difficult when the predominant plasma cells are immature or when there are few morphological features of plasma cell differentiation. ${ }^{7,21,26}$ In these cases, an erroneous diagnosis of undifferentiated acute leukaemia or another form of lymphoproliferative disease can be raised. ${ }^{7,21}$ In our case, the demonstration of monoclonality in plasma cells allowed us to make a prompt diagnosis but the use of transmission electron microscopy in order to extensively study plasma cells is advised. ${ }^{4-6,21,27}$

\section{References}

1. Kyle, R.A. Multiple myeloma. Review of 869 cases. Mayo Clin Proc 1975, 50: 29-40.

2. Pruzanski, W., Platts, M.E. \& Ogrylzo, M.A. Leukemic form of immunocytic dyscrasia (plasma cell leukemia). A study of ten cases and a review of the literature. Am J Med 1969, 47: $60-74$.

3. Pedraza, M.A. Plasma-cell leukemia with unusual immunoglobin abnormalities. Am J Clin Pathol 1975, 64: 410-415.

4. Toma, V.A., Retief, F.P., Potgieter, G.M. \& Anderson, J.D. Plasma cell leukemia. Diagnostic problems in our experience with 11 cases. Acta Haemat 1980, 63: 136-145.

5. Bassan, H., Gutmann, H. \& Djaldetti, M. Ultrastructural characteristics of the plasma cells of a patient with nonsecretory myeloma and plasma cell leukemia. Acta Haemat 1981, 66: 129-133.

6. Rubio-Félix, D., Giralt, M., Giraldo, P. et al. Nonsecretory multiple myeloma. Cancer 1987, 59: 1847-1852.

7. Bernasconi, C., Castelli, G., Pagnucco, G. \& Brusamolino, E. Plasma cell leukemia: a report of 15 patients. Eur J Haematol 1989, 43 (Suppl 51): 76-83. 
8. Serre, H., Cazel, P., Izarn, P. \& Jaffiol, C. Plasmocytome multiple est à formé osséuse pure sans dysprotéinémie et sans protéinurie. Bull Soc Med Hopitaux Paris 1958, 74: 191- 195.

9. Joyner, M.V., Cassuto, J.-P., Dujardin, P. et al. Nonsecretory multiple myeloma. $\mathrm{Br} J$ Haematol 1979, 43: $559-566$.

10. Dreicer, R. \& Alexanian, R. Nonsecretory multiple myeloma. Am J Hematol 1982, 13: 313-318.

11. Kyle, R.A., Maldonado, J.E., Bayrd, E.D. \& Minn, R. Plasma cell leukemia: report on 17 cases. Arch Intern Med 1974, 133: 813-818.

12. Zadwaski, Z.A., Kapadia, S. \& Barnes, A.E. Leukemic myelomatosis (Plasma cell leukemia). Am J Clin Pathol 1978, 70: 605-611.

13. Noel, P. \& Kyle, R.A. Plasma cell leukemia: an evaluation of response to therapy. Am J Med 1987, 83: 1062-1068.

14. Kosmo, M.A. \& Gale, R.P. Plasma cell leukemia. Sem Hematol 1987, 24: 202-208.

15. Moehring, H.D. Nonsecretory myeloma. A case report. Clin Orthop Rel Res 171: 196-201.

16. Azar, H.A., Zaino, E.C., Pham, T.D. \& Yannopoulos, K. 'Non-secretory' plasma cell myeloma: observation in seven cases with electron miscroscopic studies. Am J Clin Pathol 1972, 58: 618-623.

17. Pruzanski, W. Unusual manifestations of plasma cells dyscrasia. In: Riszman, S.E. (ed.). Pathology of Immunoglobulins: Diagnostic and Clinical Aspects, Vol. 2. Alan R. Liss, New York, 1982, p. 325.

18. Wile, L.E., Forre, O., Mathiesen, P.M.S., Hovig, T. \& Sortheberg, K. 'Non-secretory' plasma cell dyscrasia with normal serum immunoglobulins. Acta Med Scand 1978, 204: 437-441.
19. Kyle, R.A. Multiple myeloma and monoclonal gammapathies. In: Fairbanks, V.F. (ed.) Current Hematology. John Wiley and Sons, New York, 1981, p. 439.

20. Guglielmo, P., Granata, P., Di Raimond, O.F., Lombardo, T., Giustolisi, R. \& Cacciola, E. Mu heavy chain type 'non-excretory' myeloma. Scand J Haematol 1982, 29: 36-39.

21. Parreira, A., Robinson, D.S.F., Melo, J.V. et al. Primary plasma cell leukaemia: immunological and ultrastructural studies in 6 cases. Scand J Haematol 1985, 35: 570-578.

22. Sommer, I., Knobel, B., Meytes, D. \& Seidel, L. Coexistence of nonsecreting and nonproducing light chain multiple myeloma. Acta Haemat 1985, 73: 173-175.

23. Cereda, J.-M., Ayres, J. \& Gibson, T. Non-excretory myeloma. Br Med J 1982, 285: 715-716.

24. Bartoloni, C., Flamini, G., Logroscino, C. et al. IgD (kappa) 'nonsecretory' multiple myeloma: report of a case. Blood 1980, 56: 898-901.

25. Yonewaza, T., Kitani, T., Tamaki, T. Kanayama, Y., Hiraoka, A. \& Tarui, S. Immunoglobulin production and secretion in Bence-Jones protein myeloma and 'nonsecretory' myeloma: ultrastructural and immunofluorescence study. Blut 1982, 45: 121-130.

26. Osanto, S., Müller, H.P., Schuit, H.R.E., Van Nieuwkoop, J.A. \& Willemze, R. Primary plasma cell leukemia. A case report and a review of the literature. Acta Haemat 1983, 70: 122-129.

27. Polliack, A., Leiserowitz, R., Korkesh, A., Matzer, Y., Prokocimer, M. \& Gamliel, H. Plasma cell and myeloma. A scanning electron-microscopic study of cell surface features in six cases. Am J Clin Pathol 1981, 75: 834-838. 